\title{
Variability of horizontal hydraulic conductivity of fen peats from eastern Poland in relation to peatlands as natural geological barriers
}

\author{
Paweł RYDELEK ${ }^{1, *}$, Anna BĄKOWSKA ${ }^{2}$ and Piotr ZAWRZYKRAJ ${ }^{2}$ \\ 1 University of Warsaw, Department of Environmental Protection and Natural Resources, Faculty of Geology, Żwirki i \\ Wigury 93, 02-089 Warszawa, Poland \\ 2 University of Warsaw, Institute of Hydrogeology and Engineering Geology, Faculty of Geology, Żwirki i Wigury 93, 02-089 \\ Warszawa, Poland
}

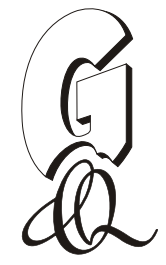

Rydelek, P., Bąkowska, A., Zawrzykraj, P., 2015. Variability of horizontal hydraulic conductivity of fen peats from eastern Poland in relation to peatlands as natural geological barriers. Geological Quarterly, 59 (2): 426-432, doi: 10.7306/gq.1180

\begin{abstract}
This paper presents the test results of horizontal hydraulic conductivity $(k)$ of fen peats from eastern Poland. Three fen peatlands in the Lubartów Plateau (3 objects marked as LP1, LP2 and LP3) and two in the Siedlce Plateau (2 objects marked as SP1 and SP2) have been selected. The objects represent a valley bog type and are similar in peat thickness, but different in area size. They also vary in terms of botanic compositions and basic physical and chemical parameters of peats. BAT permeameter was used for in situ measurements of horizontal hydraulic conductivity. Horizontal hydraulic conductivity of the peats varies from $1.3 \times 10^{-8}$ to $1.1 \times 10^{-6} \mathrm{~m} / \mathrm{s}$. The lowest values of horizontal hydraulic conductivity were observed for silted (high-ash) carbonate peats and amorphous or pseudo-fibrous peats, while the highest values were observed for unsilted (low-ash) non-carbonate peats of fibrous structure. The analysis of variability of horizontal hydraulic conductivity showed that the lowest values were observed in each case for the bottom of the studied profile. The study allowed to indicate the specific areas within the peatlands differing in permeability, and identify the role of individual objects as natural geological barriers.
\end{abstract}

Key words: hydraulic conductivity, natural geological barriers, peat, valley bog.

\section{INTRODUCTION}

According to the principles of sustainable development when designing of construction investment, not only the current state of the environment, but also the processes which may cause its future transformation should be taken into account. In order to reduce the negative effects of construction investments on soils and groundwater, it is important to identify natural geological barriers within the area of the investment or to assess the possibility of forming artificial barriers, especially in landfill designing. Cleavage (destruction) of natural geological barrier as a result of construction works, especially during road projects, is increasingly becoming a very important factor analysed in the EIA (Environmental Impact Assessment) procedures. The occurrence of natural geological barriers is also important in the protection of groundwater resources and in the determination of protection zones of groundwater intakes.

The term "natural geological barrier" is used both for soils used for sealing landfills (Langer, 1998; Dorn and Tantiwanit, 2001; Zhou and Li, 2001; Majer, 2007), as well as on a regional

\footnotetext{
* Corresponding author, e-mail: Pawel.Rydelek@uw.edu.pl
}

Received: December 12, 2013; accepted April 8, 2014; first published online: July 22, 2014 scale, for natural soil layers occurring in situ (Syrovetnik et al., 2007; Falkowska, 2009; Rydelek, 2011).

The flow of substances (including pollution), dissolved in groundwater, through a soil layer is a complex process, which consists of both a simple lifting of the solute by the groundwater flow (advection), as well as the processes of diffusion and dispersion (Bear, 1972; Hoag and Price, 1995).

Furthermore, the rate of outflow of water in organic soils is necessary for the analysis of optimal solutions in the field of foundation engineering and road embankment technology, if there are organic soils, including peats, in the subsoil of roads. Apart from mechanical parameters, filtration parameters are extremely important in the analysis of those solutions, since they determine the rate of consolidation, and thereby the rate of subsidence of realized structures. Consideration and implementation of the procedure of subsoil consolidation accelerated by overloaded embankments is conducted with detailed analysis of the outflow of water in the horizontal and vertical direction.

The rate and the range of contamination expansion as a result of the advection depend on soil properties, of which the most important is permeability. Apart from low permeability, natural geological barriers should also have a high natural sorption capacity for hazardous substances and a considerable thickness (Dorn and Tantiwanit, 2001; Falkowska, 2003; Majer, 2007). Since peats show high sorption capacity, which have been documented by many researchers (e.g., Twardowska and Kyzioł, 1996; Twardowska et al., 1999; Ho and McKay, 1999; 
Kyzioł, 2002; Allen et al., 2004; Ma and Tobin, 2004; Borkowski et al., 2013), the most important parameter determining the potential insulating capacity of peats is hydraulic conductivity $(k)$.

Hydraulic conductivity $(k)$ is one of the basic parameters used to describe permeability of fully saturated soils. According to the Darcy's law, the hydraulic conductivity is expressed in velocity units, usually in $\mathrm{m} / \mathrm{s}$. For partly saturated soil, the hydraulic conductivity is the function of the degree of saturation and suction pressure (Fredlund et al., 1996).

In mineral soils, hydraulic conductivity depends on many factors of which the most important are: the grain size distribution, structure, porosity, degree of compaction and degree of consolidation.

In the case of peats, it is hard to find similar correlation as for mineral soils, because of their composition of primarily plant material with a varying degree of decomposition. Peats are classified as exhibiting extremely high volatility of basic parameters (moisture content and ash content (Ac), directly affecting the values of density and porosity) which may also result in high volatility of hydraulic conductivity within individual peatlands (Ingram, 1978; Hobbs, 1986). Hydraulic conductivity of fen peats varies within a very wide range of $10^{-10}$ to $10^{-3} \mathrm{~m} / \mathrm{s}$, depending on the direction of filtration, type and degree of decomposition of peat, and depth (Boelter, 1965; Hobbs, 1986; Hoag and Price, 1995; Beckwith et al., 2003a, b; Rizutti et al., 2004), as well as on the research methodology applied (Dai and Sparling, 1973). In addition, hydraulic conductivity of peats may be subjected to seasonal variations due to the influence of groundwater fluctuation on shrinkage and degree of decomposition (Kennedy and Price, 2005).

Hydraulic conductivity of peats depends also on the direction of filtration. It may be caused by the morphology, orientation of plant remains and degree of decomposition. Poorly decomposed peats composed mostly of fibrous debris of reeds or sedges, horizontally oriented, exhibit a higher permeability in the horizontal direction than vertically. The increase in degree of decomposition, and the associated change of structure from fibrous to amorphous, causes a decrease of permeability and equalizes hydraulic conductivity values in the horizontal and vertical directions (Hobbs, 1986).

In order to define the role of peatlands as a natural geological barrier, a precise multi-proxy analysis of sorption properties of peats, as well as their filtration properties is required.

The aim of this study was to determine the values of horizontal hydraulic conductivity of fen peats and its variability in eastern Poland. In order to achieve the widest possible range of variation of test results, there were selected peatlands of similar thickness but different in terms of occupied area, deposits occurring in the bottom, botanical composition and basic physical and chemical parameters of peats.

\section{STUDY SITES}

Five peatlands located within the Lubartów Plateau (3 objects marked as LP1, LP2, LP3) and Siedlce Plateau (2 objects marked as SP1, SP2) were selected for the purpose of this study. Their location is presented in Figure 1.

These peatlands represent a type characteristic for both regions - elongated topographic lows within the valleys, filled with $<4 \mathrm{~m}$ thick peat - valley bogs. They are located in the valley of

the Kurówka River (LP1) or its tributaries (LP2 and LP3) and the Bystrzyca River (SP1 and SP2).

\section{MATERIALS AND METHODS}

During the in situ test, 42 measurements of horizontal hydraulic conductivity were conducted in the peatlands using a BAT permeameter. The tests were performed in 9 vertical profiles: 4 profiles in LP1 (15 measurements), 2 profiles in LP2 (8 measurements), and 1 profile (19 measurements) in each remaining peatland. The different number of studied profiles resulted from the diversity of the geological structure of individual peatlands. The measurements were performed at $50 \mathrm{~cm}$ intervals during a dry summer period. All tests were conducted at a depth greater than the groundwater table, in a zone of full soil saturation.

The BAT probe, protected by a guide pipe, is statically pressed into the soil along with a filter. The filter tip is equipped with a rubber seal. During the test, the seal is penetrated by a double ended injection needle. Conducting the test is possible after interconnection of the filter tip (placed in the soil), test container and pressure transducer (Fig. 2).

The tests were of "out flow" type. Before the test, an overpressure was generated in the test container so that the water could flow from the test container (interconnected with the filter tip) to the surrounding peat layers. The methodology of hydraulic conductivity in the BAT method is based on the gas laws (Boyle-Mariotte's, Gay-Lussac's and Clapeyron's) and the recording of the pressure changes inside the test container. Observation of the rate of these changes, directly related to the amount of flowing water and thus the permeability of the soil, allows calculation of hydraulic conductivity. Before each measurement, the value of pore water pressure was determined, which was required to calculate the horizontal hydraulic conductivity from the equation (Torstensson and Petsonk, 1986): 


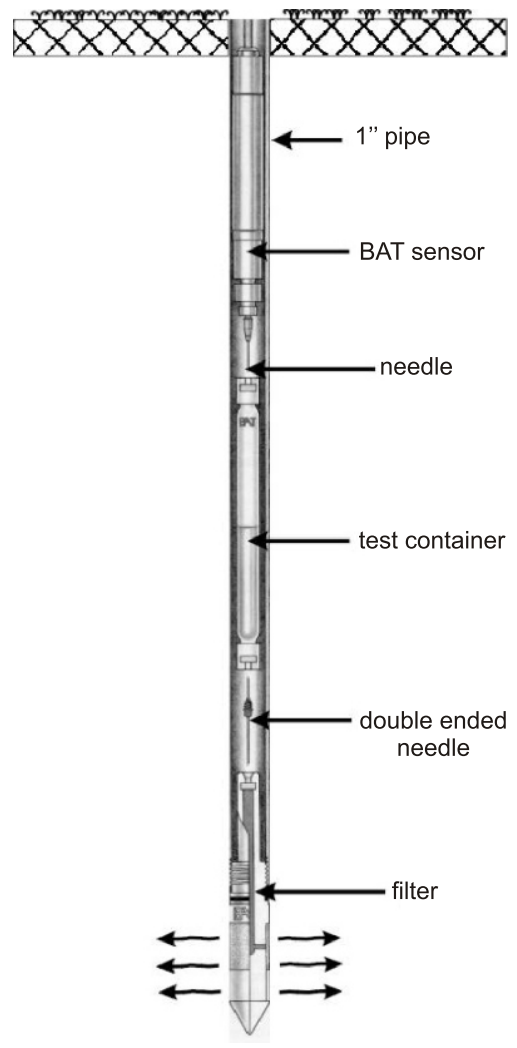

Fig. 2. Scheme of BAT piezometer (Torstensson and Petsonk, 1986, modified)

$$
k=\left(P_{0} V_{0}\right) / F t\left\{1 / P_{0} u_{0}-1 / u_{0}{ }^{2} \ln \left[\left(P_{0}-u_{0} / P_{0}\right)\left(P_{t} / P_{t}-u_{0}\right)\right\}[1]\right.
$$

where: $P_{0}$ - initial system pressure $\left[\mathrm{m} \mathrm{H}_{2} \mathrm{O}\right], P_{t}$-system pressure at time $t\left[\mathrm{~m} \mathrm{H}_{2} \mathrm{O}\right], u_{0}$ - pore water pressure in the soil [ $\mathrm{m} \mathrm{H}_{2} \mathrm{O}$ ], $t$ - time [s], $V_{0}$ - initial system volume of air $\left[\mathrm{m}^{3}\right], F-$ form factor of filter [m], defined as follows:

$$
F=2 \Pi / / \ln \{I / d+[1+(I / d) 2] 1 / 2\}
$$

where: $I$ - filter length, $d$ - filter diameter.

Basic physical and chemical properties (moisture content, ash content, carbonate content and cation-exchange capacity) were determined at the laboratory for 160 peat samples from boreholes. Cation-exchange capacity of studied peats was determined by sorption of copper (Sapek, 1982). Samples were taken each time when a macroscopic change in the composition of plant residue or degree of decomposition was noticed, but not less than every $30 \mathrm{~cm}$. The horizontal distance between the location of the BAT probe test and the boring by which the samples were taken was about $50 \mathrm{~cm}$; first the BAT test was performed, then the samples were taken.

Peat type and degree of decomposition were determined for every sample using a shortened three-step approach by Okruszko (1974): R1 - fibrous peats (poorly decomposed), R2 - pseudo-fibrous peats (moderately decomposed), R3 - amorphous peats (higly decomposed).

The study adopted the classification of peat according to the ash content proposed by Okruszko (1994): unsilted peats (ash content below $25 \%$ ), poorly silted ( $25-50 \%$ of ash) and strongly silted (50-80\% of ash). Degree of decomposition was determined only for unsilted peats (Borys, 1993).

Subdivision of peats in terms of carbonate content was based in the study on Okruszko's classification (Okruszko,

\begin{tabular}{|c|c|c|c|c|c|c|c|c|c|}
\hline Peatland & $\begin{array}{l}\text { Area } \\
\text { [ha] }\end{array}$ & Main peat type & $\begin{array}{l}\text { Thickness } \\
\text { maximum/ } \\
\text { average [m] }\end{array}$ & $\begin{array}{c}\text { Soil at the } \\
\text { bottom }\end{array}$ & $\begin{array}{l}\mathrm{Ac} \\
{[\%]}\end{array}$ & $\begin{array}{l}\mathrm{Mc} \\
{[\%]}\end{array}$ & $\begin{array}{c}\mathrm{CaCO}_{3} \\
{[\%]}\end{array}$ & $\begin{array}{c}\mathrm{CEC} \\
{[\mathrm{cmol} / \mathrm{kg}]}\end{array}$ & $\begin{array}{c}k \\
{[\mathrm{~m} / \mathrm{s}]}\end{array}$ \\
\hline LP1 & 180 & $\begin{array}{c}\text { alder peat/ } \\
\text { reed peat/ } \\
\text { tall sedge peat }\end{array}$ & $3.5 / 1.4$ & $\begin{array}{l}\text { sand, } \\
\text { locally silt }\end{array}$ & $\begin{array}{c}48.2 \\
(0.44)\end{array}$ & $\begin{array}{c}360 \\
(0.39)\end{array}$ & $\begin{array}{c}2.61 \\
(1.90)\end{array}$ & $\begin{array}{c}111 \\
(0.23)\end{array}$ & $\begin{array}{c}2.3 \times 10^{-7} \\
\min =1.5 \times 10^{-8} \\
\max =5.6 \times 10^{-7} \\
(1.13)\end{array}$ \\
\hline LP2 & 25 & $\begin{array}{l}\text { reed peat/ } \\
\text { alder peat }\end{array}$ & $3.7 / 1.5$ & sand & $\begin{array}{l}32.0 \\
(0.30)\end{array}$ & $\begin{array}{c}508 \\
(0.37)\end{array}$ & $\begin{array}{c}7.3 \\
(1.92)\end{array}$ & $\begin{array}{c}132 \\
(0.18)\end{array}$ & $\begin{array}{c}3.2 \times 10^{-7} \\
\min =2.4 \times 10^{-8} \\
\max =1.1 \times 10^{-6} \\
(1.60)\end{array}$ \\
\hline LP3 & 43 & $\begin{array}{l}\text { tall sedge peat/ } \\
\text { alder peat }\end{array}$ & $3.3 / 1.1$ & clay & $\begin{array}{c}53.6 \\
(0.32)\end{array}$ & $\begin{array}{c}329 \\
(0.33)\end{array}$ & $\begin{array}{c}32.6 \\
(0.70)\end{array}$ & $\begin{array}{c}148 \\
(0.03)\end{array}$ & $\begin{array}{c}2.4 \times 10^{-8} \\
\min =1.3 \times 10^{-8} \\
\max =4.4 \times 10^{-8} \\
(0.51)\end{array}$ \\
\hline SP1 & 275 & $\begin{array}{l}\text { tall sedge peat/ } \\
\text { reed peat }\end{array}$ & $4.0 / 1.1$ & $\begin{array}{l}\text { sand, } \\
\text { locally silt }\end{array}$ & $\begin{array}{c}18.9 \\
(0.13)\end{array}$ & $\begin{array}{l}791 \\
(0.30)\end{array}$ & $\begin{array}{c}1.2 \\
(1.30)\end{array}$ & $\begin{array}{c}133 \\
(0.21)\end{array}$ & $\begin{array}{c}3.5 \times 10^{-7} \\
\min =4.2 \times 10^{-8} \\
\max =6.5 \times 10^{-4} \\
(0.86)\end{array}$ \\
\hline SP2 & 91 & $\begin{array}{l}\text { tall sedge peat/ } \\
\text { alder peat }\end{array}$ & $3.0 / 1.0$ & sand & $\begin{array}{c}40.8 \\
(0.41)\end{array}$ & $\begin{array}{c}495 \\
(0.56)\end{array}$ & $\begin{array}{c}19.6 \\
(1.30)\end{array}$ & $\begin{array}{c}140 \\
(0.11)\end{array}$ & $\begin{array}{c}1.9 \times 10^{-7} \\
\min =5.8 \times 10^{-8} \\
\max =6.0 \times 10^{-7} \\
(1.06)\end{array}$ \\
\hline
\end{tabular}

Basic characteristics of the peatlands and average values of physical and chemical parameters of peats

$\mathrm{Ac}$ - ash content, $\mathrm{Mc}$ - moisture content, $\mathrm{CaCO}_{3}$ - carbonate content, $\mathrm{CEC}$ - cation-exchange capacity, $k$ - horizontal hydraulic conductivity, min - minimum, max- maximum, coefficient of variation given in parentheses 
1976): non-carbonate peats $\left(\mathrm{CaCO}_{3}<5 \%\right)$, poorly carbonate $(5-20 \%)$, moderately carbonate $(20-45 \%)$ and highly carbonate $\left(\mathrm{CaCO}_{3}>45 \%\right)$.

\section{RESULTS}

The peats are diverse both in terms of botanical composition and values of physicochemical parameters (Table 1).

Considering the role of peatlands as natural geological barriers, the most important parameters are: peat thickness, cation-exchange capacity (CEC) and hydraulic conductivity. The thickness of the peatlands is similar. The average CEC values in each peatland exceed $110 \mathrm{cmol} / \mathrm{kg}$, which indicates the high sorption capacity of peat (the values are much higher than those observed in mineral soils). Average values of horizontal hydraulic conductivity are similar for these peatlands (except for LP3), but the scatter of values is considerable (coefficient of variation from 0.86 to 1.60 ). Among the determined parameters, similar variability is observed only for the carbonate content.

The highest average values of horizontal hydraulic conductivity were observed in the peats of LP2 and SP1 $\left(3.2 \times 10^{-7}\right.$ and $3.5 \times 10^{-7} \mathrm{~m} / \mathrm{s}$ ), where there are peats of the lowest values of ash content $(32.0$ and $18.9 \%)$ and related highest values of moisture content. The lowest average values of horizontal hydraulic conductivity were observed in the peats of LP3 and SP2 $\left(2.4 \times 10^{-8}\right.$ and $\left.1.9 \times 10^{-7} \mathrm{~m} / \mathrm{s}\right)$, where there are highly silted carbonate peats.

Table 2 presents the average values of horizontal hydraulic conductivity depending on four criteria: peat type, ash content, degree of decomposition and carbonate content.

\section{DISCUSSION}

The research results (Table 2 ) show that peats with different botanical compositions have similar values of horizontal hy- draulic conductivity. Ash content is the main parameter affecting the values of horizontal hydraulic conductivity of the peats under study. Analysis of the relation between Ac and $k$ yielded the coefficient of determination $R^{2}=0.64$ (Fig. 3). Carbonate content and degree of decomposition have also impact on horizontal hydraulic conductivity (but they are not statistically significant, at the significance level equal to 0.05 ). The variability of horizontal hydraulic conductivity is also associated with the depth of peat layer in the vertical profile (Fig. 4).

In the non-carbonated peat profiles (all profiles of LP1 and $\mathrm{SP} 1$, one profile of LP2), a clear division into three zones was observed: bottom, middle and top zone. The highest values of horizontal hydraulic conductivity were found in the middle zone, at the average depth of $1.5 \mathrm{~m}$, where there are poorly decomposed peats of R1 degree of decomposition and lowest values of ash content. The lowest values of horizontal hydraulic conductivity were found at the bottom of peat profile, where there are strongly silted peats.

In the profiles where non-carbonated peats occur only at the top (up to $1 \mathrm{~m}$ depth) and carbonate peats constitute the rest of the profile (one profile of LP2 and SP2), there is a clearly marked "jumping" decrease of horizontal hydraulic conductivity value from a depth of $1 \mathrm{~m}$.

The lowest values of horizontal hydraulic conductivity were observed in profile LP3, where there are strongly silted and strongly carbonate peats observed through the whole thickness of the profile.

In all of the peatlands, regardless of their peat properties, the lowest values of horizontal hydraulic conductivity were found in the deepest parts of the profiles, which is probably related to overburden pressure.

In peatlands LP3 and SP2, where the lowest values of horizontal hydraulic conductivity were observed $\left(2.4 \times 10^{-8}\right.$ and $1.9 \times 10^{-7} \mathrm{~m} / \mathrm{s}$ ), there was also the highest $\mathrm{CaCO}_{3}$ content. Calcium carbonate occurs in the peats in the form of microcrystals of idiomorphic habit, which indicates the crystallisation within the peat deposit and autogenesis (Rydelek, 2013). The calcite

T a ble 2

Average values of hydraulic conductivity depending on the peat type, ash content, degree of decomposition and carbonate content (numbers of measurements in parentheses)

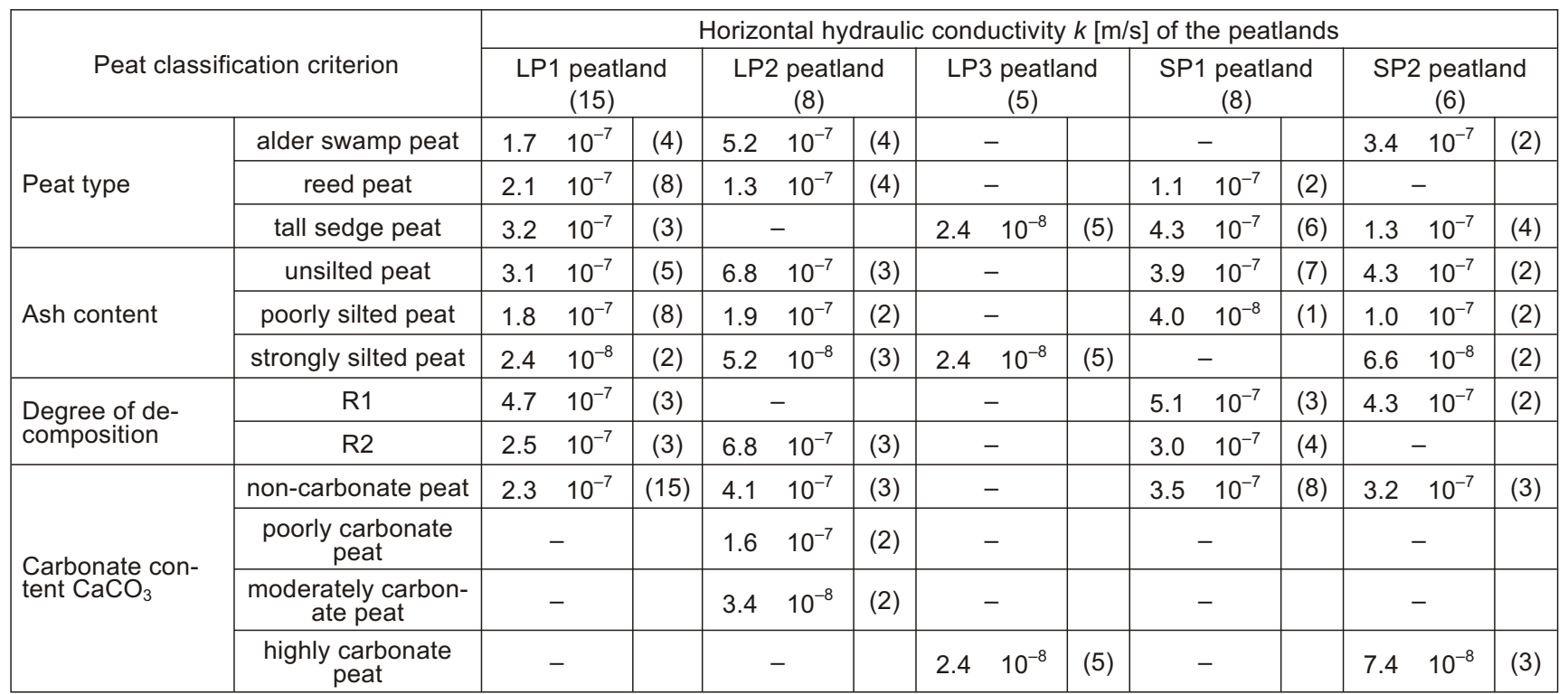




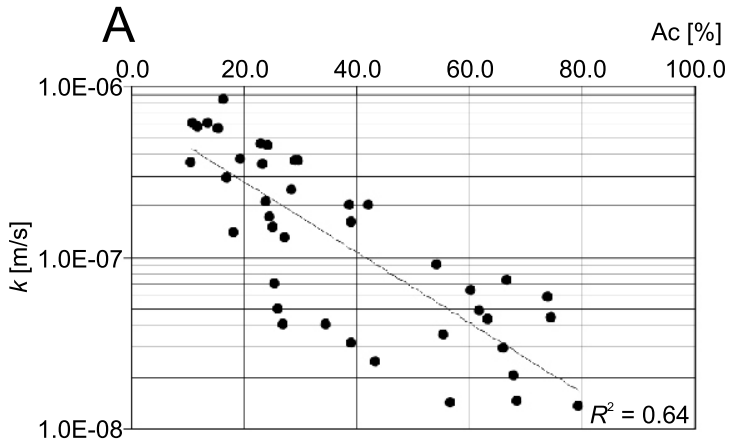

C

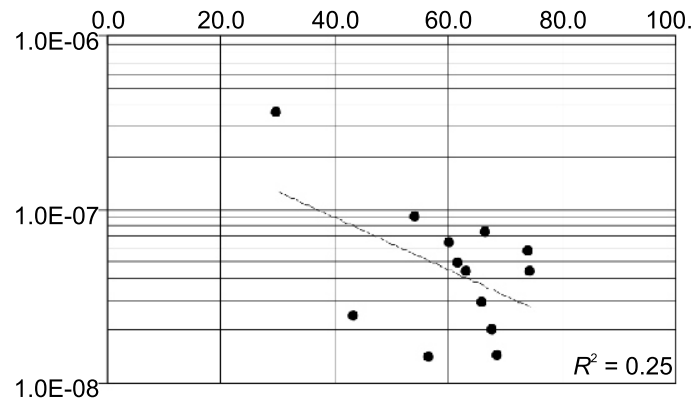

$E$

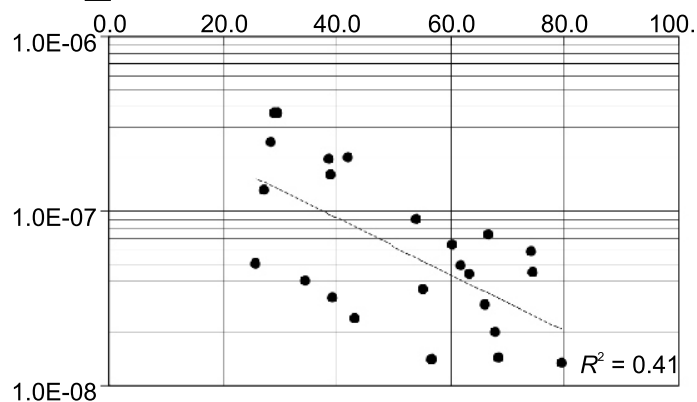

G

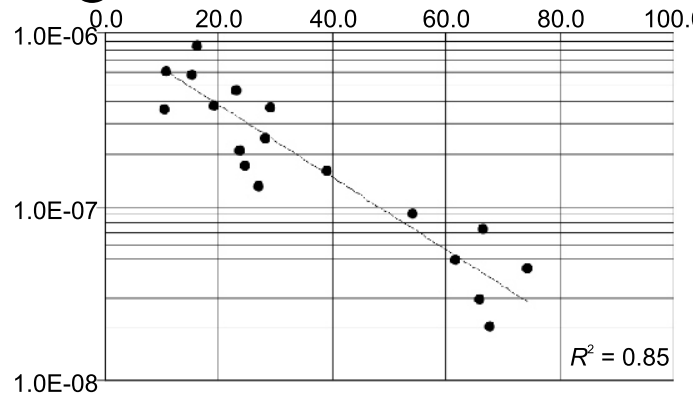

B

Ac [\%]

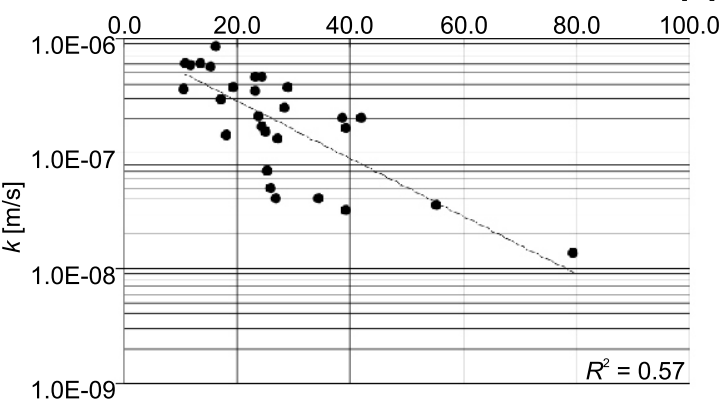

$\mathrm{D}$

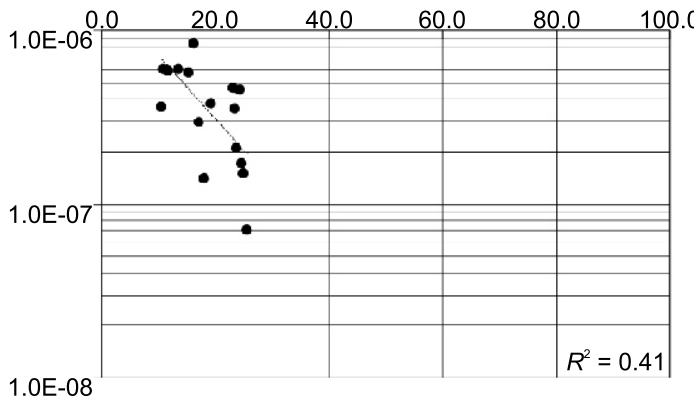

$\mathrm{F}$

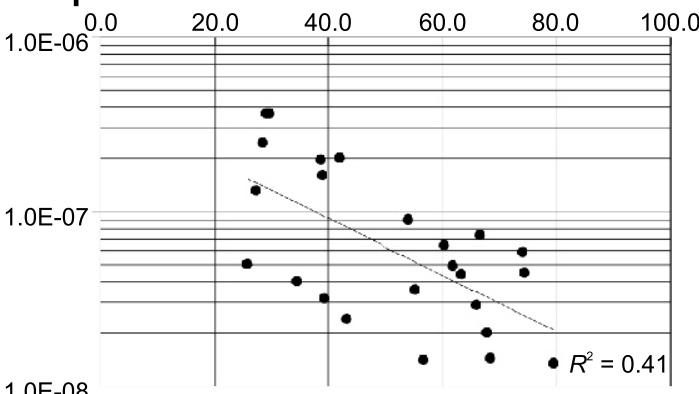

\section{$\mathrm{H}$}

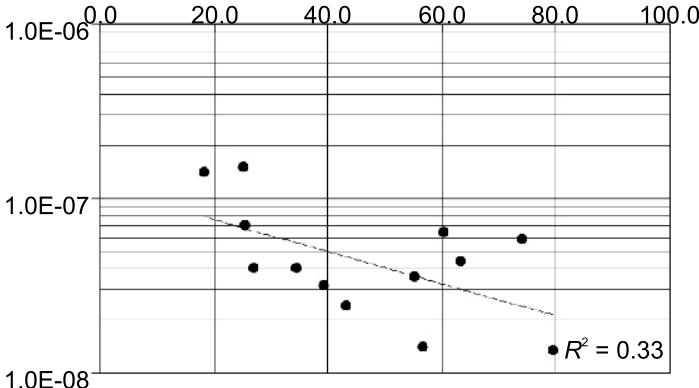

Fig. 3. Relationship between hydraulic conductivity $(k)$ and ash content (Ac) in the peatlands

A - for all peat samples; $\mathbf{B}$ - for non-carbonate peats $\left(\mathrm{CaCO}_{3}<5 \%\right) ; \mathbf{C}$ - for carbonate peats $\left(\mathrm{CaCO}_{3}>5 \%\right)$;

D - for unsilted peats (degree of decomposition R1 and R2); $\mathbf{E}$ - for silted peats; $\mathbf{F}$ - for peats from a depth down to $1 \mathrm{~m} ; \mathbf{G}$ - for peats form a depth between 1 and $2 \mathrm{~m} ; \mathbf{H}$ - for peats from a depth $>2 \mathrm{~m}$ 


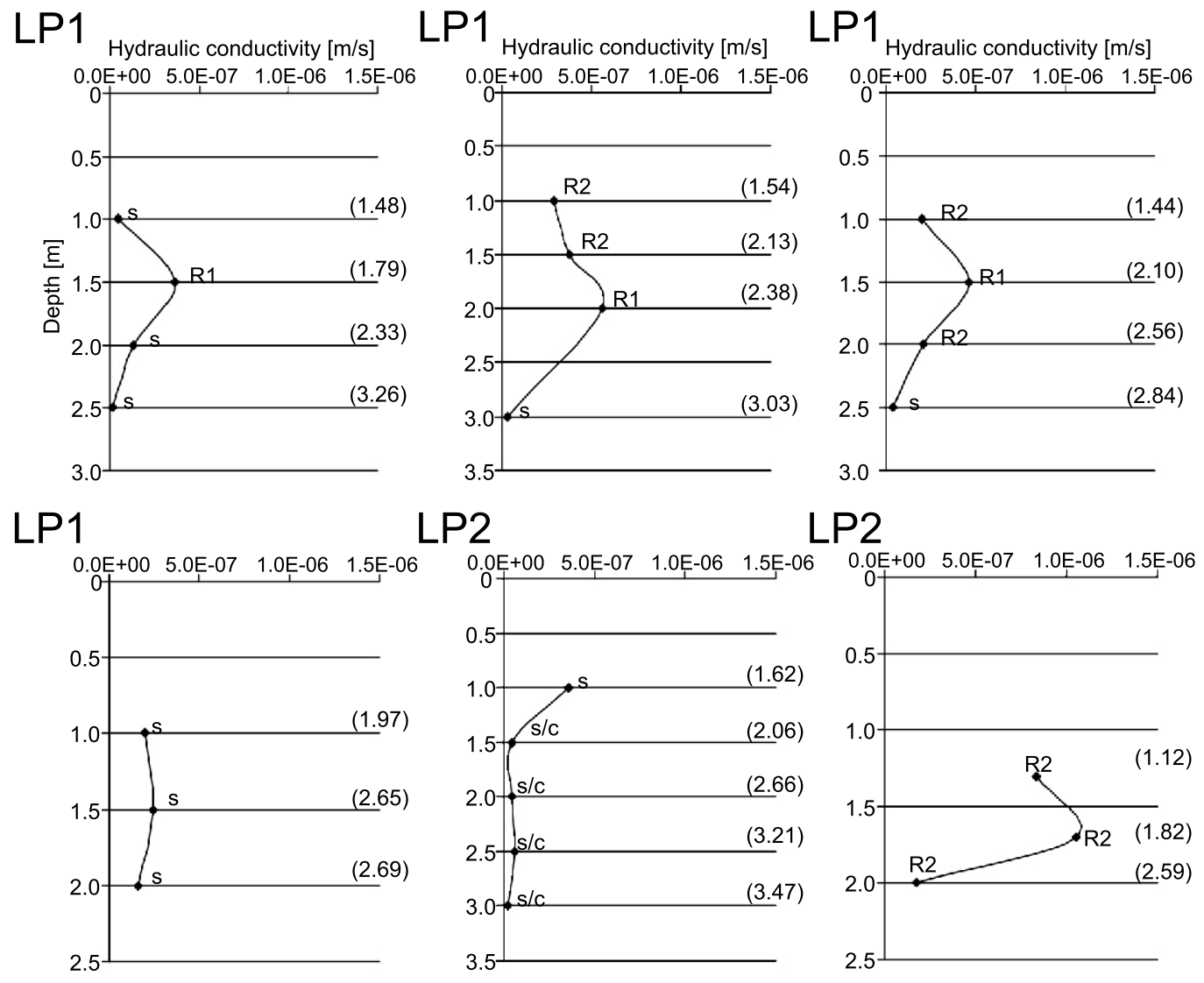

LP3

SP2

SP1

$0.0 \mathrm{E}+00 \quad 5.0 \mathrm{E}-07 \quad 1.0 \mathrm{E}-06 \quad 1.5 \mathrm{E}-06$
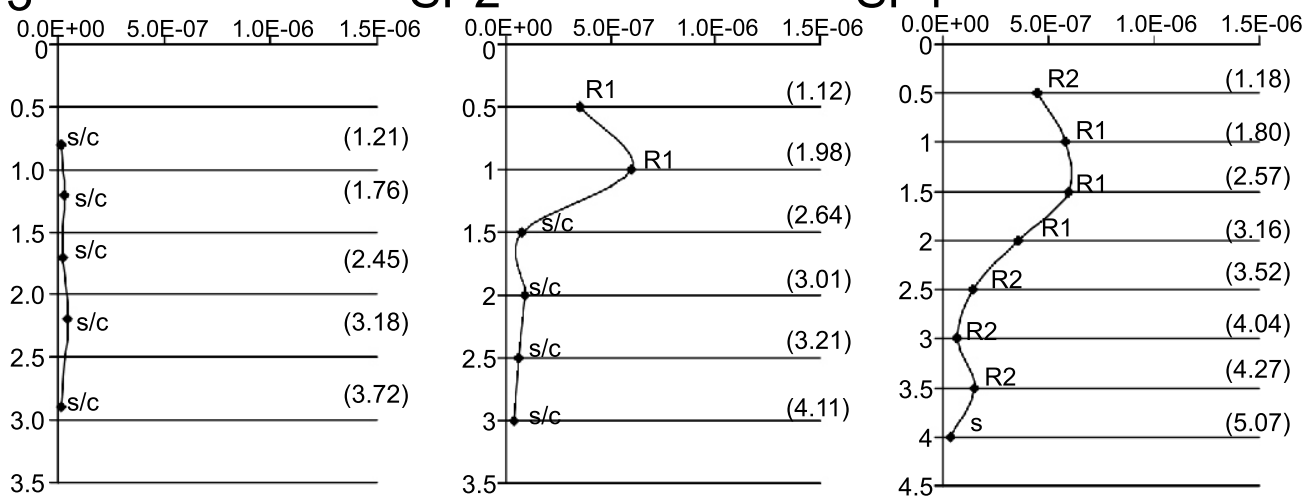

Fig. 4. Variability of horizontal hydraulic conductivity in vertical profiles of the peatlands

$\mathrm{R} 1, \mathrm{R} 2$ - degree of peat decomposition, $\mathrm{s}$ - silted peat, s/c - silted peat/carbonate peat, initial system pressure $P_{0}\left[\mathrm{~m} \mathrm{H}_{2} \mathrm{O}\right]$ given in parentheses

crystals, while crystallizing in the pore space, reduce the effective porosity, "clogging" macropores, which can reduce the horizontal hydraulic conductivity.

Laboratory tests of hydraulic conductivity of studied peats in the Rowe-Barden chamber show that values of hydraulic conductivity in vertical direction varies form $3.1 \times 10^{-8}$ to $5.1 \times 10^{-9}$ $\mathrm{m} / \mathrm{s}$ and are lower than values in horizontal direction from BAT tests (Rydelek, 2006).

\section{SUMMARY AND CONCLUSIONS}

The paper presents a multi-proxy analysis of five fen peatlands from eastern Poland. The peatlands have similar thickness and high sorption capacity of peats, but also show a considerable variation of horizontal hydraulic conductivity. The value of horizontal hydraulic conductivity is mainly influenced by the physical properties of peats: ash content and degree of decomposition. The highest values of horizontal hydraulic conductivity in all peatlands were observed in the peats with the lowest ash content (unsilted peats) and decomposition degree R1. However, there is no clear impact of botanical composition (type of peat) on the value of horizontal hydraulic conductivity.

Chemical properties of peats also affect the value of horizontal hydraulic conductivity. In the peats of similar ash contents, lower conductivity was observed in the peats with a higher content of authigenic calcium carbonate filling the pore space. 
The peatlands also showed the characteristic variability of horizontal hydraulic conductivity in vertical profiles. The lowest horizontal hydraulic conductivity was observed in the bottom zone, which is most likely related to both a lower content of organic matter and porosity reduction caused by overburden pressure. Therefore, the top zones of the peats have potentially worse insulating properties than the bottom layers.
Carbonate peatlands may be thus potentially better natural geological barriers among all of the studied peatlands because of their low values of horizontal hydraulic conductivity and high values of cation-exchange capacity.

Acknowledgements. The authors wish to thank all those involved in the review of this paper.

\section{REFERENCES}

Allen, S.J., McKay, G., Porter, J.F., 2004. Adsorption isotherm models for basic dye adsorption by peat in single and binary component systems. Journal of Colloid and Interface Science, 280: 322-333.

Bear, J., 1972. Dynamics of Fluids in Porous Media. American Elsevier, New York.

Beckwith, C.W., Baird, A.J., Heathwaite, A.L., 2003a. Anisotropy and depth-related heterogeneity of hydraulic conductivity in a bog peat. I: laboratory measurements. Hydrological Processes, 17: 89-101.

Beckwith, C.W., Baird, A.J., Heathwaite, A.L., 2003b. Anisotropy and depth-related heterogeneity of hydraulic conductivity in a bog peat. II: modelling the effects on groundwater flow. Hydrological Processes, 17: 103-113.

Boelter, D.H., 1965. Hydraulic conductivity of peats. Soil Science, 100: 227-231.

Borkowski, A., Rydelek, P., Szala, M., 2013. Adsorption studies of azotetrazolate and 3,6-dihydrazinotetrazine on peat. Journal of Environmental Science and Health, Part A, 48: 905-911.

Borys, M., 1993. Niskie nasypy z miejscowych gruntów organicznych dla potrzeb budownictwa wodno-melioracyjnego (in Polish). Wydawnictwo IMUZ, Falenty.

Dai, T.S., Sparling, J.H., 1973. Measurement of hydraulic conductivity of peats. Canadian Journal of Soil Science, 53: 21-26.

Dorn, M., Tantiwanit, W., 2001. New methods for searching for waste disposal sites in the Chiang Mai-Lamphun basin, northern Thailand. Environmental Geology, 40: 507-517.

Falkowska, E., 2003. Sorption of $\mathrm{Pb}$ and $\mathrm{Cd}$ by sediments of the polygenetic river valleys of the eastern part of the Polish Lowland. Geological Quarterly, 47 (2): 169-186.

Falkowska, E., 2009. Glacial morphogenesis of uplands of the Warta Glaciation in Poland as a control on heavy metal distribution in deposits. Geological Quarterly, 53 (3): 293-304.

Fredlund, D.G., Xing, A., Fredlund, M.D., Barbour, S.L., 1996. The relationship of the unsaturated soil shear to the soil-water characteristic curve. Canadian Geotechnical Journal, 33 440-448.

Ho, Y.S., McKay, G., 1999. The sorption of lead (II) ions on peat. Water Research, 33: 578-584.

Hoag, R.S., Price, J.S., 1995. A field-scale, natural gradient solute transport experiment in peat at a Newfoundland blanket bog. Journal of Hydrology, 172: 171-184.

Hobbs, N.B., 1986. Mire morphology and the properties and behaviour of some British and foreign peats. Quarterly Journal of Engineering Geology and Hydrogeology, 19: 7-80.

Ingram, H.A.P., 1978. Soil layers in mires: function and terminology. Journal of Soil Science, 29: 224-227.

Kennedy, G.W., Price, J.S., 2005. A conceptual model of volume-change controls on the hydrology of cutover peats. Journal of Hydrology, 302: 13-27.

Kyzioł, J., 2002. Effect of physical properties and cation exchange capacity on sorption of heavy metals onto peats. Polish Journal of Environmental Studies, 11: 713-718.
Langer, M., 1998. Engineering geological evaluation of geological barrier rocks at landfills and repositories. Environmental Geology, 35: 19-27.

Ma, W., Tobin, J.M., 2004. Determination and modelling of effects of $\mathrm{pH}$ on peat biosorption of chromium, copper and cadmium. Biochemical Engineering Journal, 18: 33-40.

Majer, E., 2007. Metodyka doboru gruntu w ramach projektowania mineralnych przesłon izolacyjnych składowisk odpadów (in Polish). Geologos, 11: 239-252.

Okruszko, H., 1974. Zasady podziału gleb organicznych (in Polish). Wiadomości Instytutu Melioracji i Użytków Zielonych, 12: 19-38.

Okruszko, H., 1976. Zasady rozpoznawania i podziału gleb hydrogenicznych z punktu widzenia potrzeb melioracji (in Polish). Biblioteczka Wiadomości Instytutu Melioracji i Użytków Zielonych, 52: 7-54.

Okruszko, H., 1994. System of hydrogenic soil classification used in Poland. Biblioteczka Wiadomości Instytutu Melioracji i Użytków Zielonych, 84: 5-27.

Rizzuti, A.M., Cohen, A.D., Stack, E.M., 2004. Using hydraulic conductivity and micropetrography to assess water flow through peat-containing wetlands. International Journal of Coal Geology, 60: 1-16.

Rydelek, P., 2006. Wpływ zróżnicowania właściwości fizykochemicznych torfów niskich na zdolności izolacyjne torfowisk wysoczyzny lubartowskiej (in Polish). Ph.D. thesis. Arch. UW, Warszawa.

Rydelek, P., 2011. Peatlands of Lubartów Upland as the potential natural geological barriers (in Polish with English summary). Biuletyn Państwowego Instytutu Geologicznego, 446: 407-416.

Rydelek, P., 2013. Origin and composition of mineral constituents of fen peats from Eastern Poland. Journal of Plant Nutrition, 36: 911-928.

Sapek, B., 1982. Pomiar sorpcji miedzi jako test oceny pojemności sorpcyjnej utworów organicznych (in Polish). Roczniki Gleboznawcze, 38: 343-349.

Syrovetnik, K., Malmström, M.E., Neretnieks, I., 2007. Accumulation of heavy metals in the Oostriku peat bog, Estonia: determination of binding processes by means of sequential leaching. Environmental Pollution, 147: 291-300.

Torstensson, B.A., Petsonk, A.M., 1986. A device for in-situ measurement of hydraulic conductivity. In: Proceedings of the 4th International Seminar Field Instrumentation and In-situ Measurements: 157-162. Nanyang Technical Institute, Singapore.

Twardowska, I., Kyzioł, J., 1996. Binding and chemical fractionation of heavy metals in typical peat matter. Fresenius' Journal of Analytical Chemistry, 354: 580-586.

Twardowska, I., Kyzioł, J., Goldrath, T., Avnimelech, Y., 1999. Adsorption of zinc onto peat from peatlands of Poland and Israel. Journal of Geochemical Exploration, 66: 387-405.

Zhou, W., Li, G., 2001. Geological barrier - a natural rock stratum for preventing confined karst water from flowing into mines in North China. Environmental Geology, 40: 1003-1009. 